\title{
Jesuítas: os Mestres do Neengatú
}

\section{MARIA LEÔNIA CHAVES DE RESENDE*}

Resumo: Esse artigo procura resgatar a visão que os guarani tiveram do processo de catequese nas missōes jesuíticas. Procuramos compreender a leitura que os guarani fizeram sobre o uso da língua como instrumento de conversão.

Abstract: This article aimes to recall the vision that the guarani had of the catechism process in the jesuitcs missions; tries to comprehend the reading that the guarani did about the use of the language as an instrumnet to conversion.

Palavras-chave: Etno-História guarani. Contato interétnico. Catequese.

Key words: Etno-History. Interethnic contacts. Cathecism.

\section{Introdução}

A Companhia de Jesus inaugurou, em terras do Novo Mundo, uma experiência inédita com os guarani - as missões com o objetivo de realizar seu grande intento de conquista espiritual dos nativos. Essa experiência suscitou um longo e controvertido debate dentro da própria ordem. Além de uma série de empecilhos acerca da natureza do gentio, a Companhia ainda se deparou com seus próprios dilemas de ordem ética e moral. Muitos padres se viram embaraçados com muitas situações. As cartas jesuíticas estão repletas de incertezas de como conduzir a catequese, especialmente dos nativos. Talvez, por isso mesmo, os métodos adotados pelos jesuítas na catequese tenham sido pouco usuais. De qualquer forma se espraiaram em profusão por toda a Ordem, embora não tenham sido aceitos facilmente.

* Doutoranda em História Social na UNICAMP. Professora no Departamento de Ciências Sociais da FUNREI/M. G. E-mail: leonia@funrei.br 
Enseadas de debate teológico, a resistência e crítica ao métodos jesuíticos de conversão logo apareceram. No entanto, diante de tantos precedentes, muitos desses recursos foram utilizados pelos padres. Afinal, visavam à catequese e em nome dela muitas práticas se justificavam. Assim, como conduzi-la? Em nome desse objetivo, os jesuítas buscavam, na experiência cotidiana, aqueles recursos mais eficientes.

\section{O discurso da aproximação: ensaio dos primeiros contatos}

A conversão significava persuadir e convencer. Portanto a língua, naturalmente, era o acesso fundamental. No Brasil, um ano após a chegada dos primeiros jesuítas, o padre João de Azpilcueta Navarro, enviado por Nóbrega a Porto Seguro, já se preocupava com essa questão. Ele se incumbia de entender-se com "bons línguas", como eram chamados os intérpretes, para traduzir em idioma da terra, orações e sermões com fins catequéticos (Cartas Avulsas, 1988, II, p. 97; IV, p. 101).

Nessa ocasião, Pe. Aspilcueta Navarro já proferia missa e ensinava na língua nativa, traduzia a criação do mundo e a encarnação, além dos demais artigos da Fé e mandamentos da Lei, especialmente o Padre Nosso. As peripécias do jesuíta foram descritas em detalhes no apêndice ao relatório quadrimestral de 1557: "Tinha traças originais de orar, ensinar e corrigir: falava aos índios fazendo visagens, dando gritos, batendo com o pé, para impressionar [...]". Antônio Pires reconhecia a importância do trabalho de Navarro pelas suas preciosas traduções. Reclamava das dificuldades que todos tinham pela "falta em carecer da língua e não saber declarar aos índios o que queremos por falta de intérpretes que saibam explicar e dizer como queremos" (Cartas Avulsas, 1988, I, p. 76).

Como boa parte dos irmãos da Companhia ainda não dominava com segurança a língua, muitos foram obrigados a recorrerem aos intérpretes. Abrindo mão do sigilo da confissão, coisa inédita e admirável da Companhia, compartilhavam suas dúvidas, sem maiores constrangimentos doutrinários. As dúvidas que decorriam das confissões eram propostas ao Padre Superior, à hora do repouso, para que desse sua resolução (Cartas Avulsas, 1988, II, p. 183). De qualquer forma, muitos se viram obrigados a pregar e ministrar a missa através de um intérprete. 
Talvez, por esse tipo de desconforto, as investidas iniciais de Navarro no aprendizado da língua tenham agigantado o interesse de todos. O Irmão Antônio Rodrigues entrava para a Companhia em 1553, em São Vicente, e aperfeiçoava o fruto de Navarro. Domingos Pecoreta, "perito na língua brasílica, fazia pelas aldeias grande fruto nos índios". No colégio da Bahia, se instituíram várias aulas e classes, obrigatórias a todos os religiosos: a do idioma da terra teve seu lugar assegurado (Cartas Avulsas, 1988, II, p. 150). Os padres se viram, dessa forma, obrigados a treinarem a língua nativa. No relatório quadrimestral de 1556, sobre as atividades no Brasil, Padre Inácio era informado com grande entusiasmo dos resultados desse procedimento:

"[...] até então não se tinha ensinado com tanto concerto, nem tínhamos as orações da doutrina tão bem trasladadas e não havia senão o padre Navarro que sabia a língua razoavelmente. Mas agora que o Irmão lhes começou a declarar em sua língua os Artigos da Fé e as mais orações e fazendo-lhes práticas e declarações sobre elas, lhe sobreveio um novo fervor, engodados, segundo eu cuido, pela novidade da cousa. Assim que com antes não avirem senão 12 pessoas, então se ajuntaram quase duzentas, as quais têm cobrado tanta devoção [...]"' (Cartas Avulsas, 1988, II, p. 183).

A fama dos jesuítas corria por toda terra. Antônio Pires, em 1552, expressava bem a importância dessa prática: "O Padre lhes deu [aos índios] por um Padre que fosse letrado e pregador, porque esta fama de letrado faz muito ao propósito" (Cartas Avulsas, 1988, II, p. 147). Com essa conduta, a Companhia de Jesus incumbirá aos "línguas" da Ordem o encargo da catequese. Por ser experiente no assunto, encarregaram ao irmão Antônio Pires, "das melhores línguas que temos", das novas entradas. Recomendavam ao seu substituto, o Pe. Ambrósio Pires, "mui expressamente aprendesse a língua em a qual por então se exercitava". O resultado foi esplêndido, contava o Irmão Antônio Blasquez, em 1556, na Bahia: "como então lha declaravam na sua língua, com algumas práticas e declarações dela, cousa por eles nunca vista, cresceu em seus corações um novo desejo de aprenderem as cousas da Fé" (Cartas Avulsas, 1988, II, p. 185,179). Simão de Vasconcelos, falando do Seminário na Bahia, a Confraria de Meninos Índios a cargo do Pe. Salvador Rodrigues, afirmava que o sucesso foi a tal ponto que era opinião de Nóbrega ser esse um dos métodos para se converter a gentilidade do Brasil. Para tanto, insistia na versão para a língua gentílica de tudo quanto se pudesse. 
Parece que os jesuítas não abriram mão de seus métodos. Quase um século depois, na América hispânica, o padre provincial Francisco Vásquez instruía e confessava através de seus intérpretes. Sua atitude também trouxe admiração a um dos curas, "que espantado con a grande novedad pregunto se (era licito) confessar de aquela suerte". Se a cautela de Nóbrega ficou clara, pelo menos nos primeiros momentos, Padre Romero, na América hispânica, não hesitava e afirmava em tom categórico: "no es posible que viendo una miez tan copiosa y dispuesta no rompa con todo por cogerla" (Documentos, 1929, 388, 394, 395; Cortesão, 1951, III, p. 91). Será precisamente essa a conduta adotada pelos jesuítas nas missões guarani poucas décadas depois.

A discussão sobre a importância do conhecimento da língua se aprofunda não só na exigência da comunicação com a comunidade indígena mas sobretudo pela realização, em sentido amplo, de uma política lingüística. Toda essa discussão, por isso, deve ser nuançada. Se considerarmos que a língua foi um instrumento de controle e dominação, como querem sugerir alguns, é preciso inserir essa questão em seu momento histórico. É preciso entender o procedimento dos jesuítas também a partir da conjuntura que estava colocada. Por isso, é fundamental percorrer com eles o momento dos primeiros contatos, instante em que a questão da comunicação, e portanto da língua, seria o centro das preocupações da Ordem.

Por outro lado, há de se contemplar a perspectiva indígena. Compreender como o nativo se portou frente à tentativa sistemática dos padres de dominarem a língua. Se a pedagogia jesuítica é motivo de atenção, porque se mostrou criativa e original, deve-se considerar a contrapartida indígena. E a resposta guarani apareceu justamente no momento de sua redução nas missões. Em uma situação crítica em que se sentiram ameaçados na sua identidade, na preservação de seus valores, os guarani expressaram, talvez como em nenhum momento, a sua percepção de mundo. Resistindo à sua maneira, registraram, assim, o "ethos" de seu povo. Com esse objetivo, recuperamos essa trajetória nas missões jesuíticas da América hispânica.

\section{A leitura da Ordem: a versão jesuítica}

No início do século XVII, a Companhia de Jesus implementava sua iniciativa religiosa no Guaíra a cargo dos 
padres Cataldino e Maceta. Lá os jesuítas realizariam uma das mais fascinantes obras evangélicas do Novo Mundo. É nessa viagem fantástica e cheia de peripécias que vamos rever as primeiras tentativas de contato para fundar as tão desejadas missões. Experiência intrépida que marcará o destino de toda uma nação indígena: os guarani.

Em 1609, os padres saíram de Assunção, em direção ao oriente, atravessando aquelas paragens, inóspitas e agrestes, num percurso, através dos rios, durante um período de trinta a quarenta dias, na tentativa de reduzir os indígenas em missões. Com duas árvores de boa espessura, atadas por varas de vime, construía-se uma balsa na qual os índios assentavam cana de bambu entre os troncos e levantavam uma choça. Revestiam-na com um telhado também de palha e cobriam-na com couros de boi. É nessa embarcação bizarra que os missionários passaram boa parte do tempo, como se em terra firme, entre seus escritos, leituras e seus exercícios espirituais, nessa longa trajetória até o Guaíra, durante a primeira tentativa de ocupação.

A chegada dos jesuítas na América hispânica nos lembra uma verdadeira epopéia. A tropicalidade é bem desenhada, descendose aos detalhes próprios da Companhia de Jesus. Mas, nas descrições, aos trópicos de natureza hostil e adversa esbarrava a sagacidade da Companhia. Com a determinação da Ordem, o jesuíta fazia das barreiras intransponíveis o estímulo para seu empreendimento. Resolutos e destemidos, levando à mão uma grande cruz para mostrar sua pregação por meio daquela insígnia, os padres percorreram nessa primeira empresa dezoito anos de desventuras. ${ }^{1}$

Enviados pelo Padre Provincial Diogo de Torres, os jesuítas José Cataldino e Simão Masseta, apóstolos daquela gentilidade, já chegaram ao Guaíra enfermos e sem assistência médica. Lá penaram até a convalescência. Obstinados em anunciar a salvação eterna, os padres perseveravam em nome da conversão do gentio, seguindo viagem ainda por mais dez ou doze dias. Aquelas alturas, navegaram até, por fim, encontrarem um povoado, à beira,

\footnotetext{
Pe. Antônio Ruiz de Montoya, na Conquista espiritual feita pelos religiosos da Companhia de Jesus nas Províncias de Paraguai, Paraná, Uruguai e Tape. Trad. Arnaldo Bruxel. Porto Alegre: Martins Livreiro, 1985, 1. ed. bras., p. 38. As descrições aqui apresentadas foram extraídas desse relato. Mas também são encontradas reproduzidas nos Anais da Biblioteca Nacional, Vol. VI, traduzido pelo Dr. Baptista Caetano de Almeida Nogueira. Recorreremos ao primeiro relato como referência. A partir de agora, faremos menção à obra como Montoya. Quando for o caso, discriminaremos a indicação do texto original citando como Anais.
} 
cercado por um grande arroio, onde viviam cerca de duzentas almas. Ali assentaram o estandarte da cruz, ergueram uma pequena cabana como igreja e nomearam esse arrabalde com o título de Nossa Senhora de Loreto - a primeira missão. Anunciaram, assim, ao povoado e aos lugarejos vizinhos a razão de sua vinda: "fazêlos filhos de Deus e libertá-los da escravidão e do demônio" (Montoya, 1985, p. 40).

Passados seis meses da ocupação das adjacências do Pirapó, onde se estabelecera a primeira missão da América hispânica, Nossa Senhora de Loreto, e um ano desde que os dois missionários lançaram-se na empresa evangélica, o Padre Diogo de Torres enviou para aquela província dois novos jesuítas - os padres Antônio Ruiz de Montoya e Moranta. Por volta de 1611, Padre Montoya toma a liderança das fundações e seu nome seria lembrado na história como o grande mentor da conquista espiritual pela sua ação evangélica e pelas suas produções literárias em língua guarani.

Sem temerem os percalços de seus empreendimentos, Montoya e seu companheiro partiram para a viagem que os levaria ao Guaíra. Montoya, durante os poucos dias que permaneceu na região do porto de Maracaju, em suas peregrinações pelos campos ministrava os sacramentos aos índios que encontrava. Aproveitando-se da oportunidade, treinava o guarani, falava e ouvia o gentio, aperfeiçoando-se em sua língua, ao mesmo tempo que observava os costumes indígenas.

A tarefa da conversão se impunha. Confrontar-se com aquela "imensidão de almas perdidas" aguçava a determinação dos jesuítas que ansiavam em "ganhar terra e almas para o céu". Para tanto, os padres José e Montoya precisavam penetrar sertão adentro para convidarem os índios a se reduzirem em povoações, em lugares que lhes haviam de apontar. Assim, enfrentando novos riscos e reveses, desbravaram florestas, alçaram serras até esbarrarem com outras terras indígenas.

Acompanhando essa expedição, seguiam um pouco à frente "exploradores de terras para que eles, em se lhes oferecendo ocasião propícia, dessem informe a respeito dos intentos daqueles missionários" (Montoya, 1985, p. 48). Esse conselho, dado pelos próprios neófitos, índios recém-convertidos, tornou-se prática bastante comum nas inúmeras investidas da Companhia de Jesus que se seguiriam. Por essa razão, desde a primeira viagem dos Padres José e Simão, eles foram acompanhados por um vizinho do Guaíra, a título de "línguaraz" ou intérprete. Assim, informava tudo aos jesuítas e se colocava como intermediário na comunica- 
ção entre os missionários e a comunidade. Nem sempre, contudo, a interferência desse intérprete da comitiva foi favorável.

Exemplo disso, haviam cometido os padres José e Cataldino que, acompanhados por um leigo espanhol, viram-se ameaçados de descrédito entre o gentio no Guaíra. Os padres não perceberam que as intenções do intérprete eram, de fato, as de um negociante. A cada visita que ele fazia nas cabanas voltava ora sem seu chapéu ora sem seus pertences. Até, finalmente, ver-se reduzido aos retalhos que lhe cobriam o corpo e um lenço amarrado à cabeça. Estranhando aquele despojamento, perguntaram-lhe os padres o sentido daquela atitude. Prontamente o espanhol respondeu que "os padres pregavam ao seu modo e ele do seu". Não sendo afeito às palavras, pregava em "obras": repartia tudo quanto trazia ou possuía para "conquistar a vontade dos índios principais, porque, ganhos estes, os demais ficariam à sua mercê".

Posto isso, grande admiração tomaram os padres pelo zelo e perspicácia do espanhol. Não se aperceberam, porém, que, por detrás das suas atitudes se escondia um grande embuste: com cada uma das peças de que se desprovia, tinha ele comprado uma índia ou criança. Pouco restava aos missionários senão lamentar, se os índios não tivessem julgado que o "leilão" se fazia por ordem dos padres. Os jesuítas, desmoralizados diante da comunidade, recorreram a muitos esforços e explicações para recuperarem a confiança e, enfim, recobrarem novamente o crédito do gentio (Montoya, 1985, p. 38, 48).

Para resguardarem sua credibilidade, após essa experiência, os padres mudam sua estratégia de contato. Com freqüência, passaram a utilizar os próprios indígenas, recém-convertidos, nessa empresa. Algumas manobras desse tipo lograram também entre as entradas posteriores dos padres Ruiz de Montoya, José e Diogo de Salazar. Acompanhados pelos seus "informantes", agora dois jovens índios neófitos, um deles criado entre os missionários, os jesuítas prosseguiram sua empreitada. Antecipando-se aos padres, os índios anunciavam nas novas terras a determinação dos jesuítas em lhes pregar o Evangelho. Mas nem bem haviam se animado com sua arenga, pregando a boa nova ao gentio, os índios daquela localidade prenderam os intermediários com o desejo de matá-los. Com enorme alarido, oferecem-lhes "de imediato mulheres, desafogo e liberdade de consciência”. Um deles, o índio convertido, resistiu à oferta, e nem mesmo se seduziu aos encantos bem afeiçoados da jovem que lhe foi presenteada. O outro logo se amancebara, pouco usufruindo de seus deleites. Ao cabo de poucos dias, 
em uma solenidade, festejaram com sua morte e devoraram-no (Montoya, 1985, p. 84).

Assustados com a grandeza de tal atrocidade, puseram-se os padres a apressar os passos para a conversão do gentio. Assim, se asseguraram em um pequeno povoado, resguardando-se contra as investidas daqueles que, pouco satisfeitos com a degola dos informantes e assustados com a presença dos missionários na vizinhança, precipitaram-se como corja contra os padres. Aproximando-se o perigo que se acercava dos missionários, grande tumulto e perturbação tomou o povoado.

Esse infortúnio teria logo seu desfecho, se pela "providência divina", dizia Montoya, não lhes acorresse em visita um cacique principal, em sua defesa. Fato é que esse cacique foi ao encontro dos perseguidores que já rodeavam a vizinhança do povoado. Com ar soberbo, aquele cacique mudaria a sorte dos padres. Ao defrontar-se com eles, o cacique fez um discurso sobre as razões que justificavam a presença dos estrangeiros:

"não tinham a finalidade de pelejar, pois estavam desarmados; não tirariam-lhe ouro ou prata, pois nada possuiam, queriam sim fazêlos filhos de Deus e ensinar-lhes o modo de bem viver" (Anais, 1878, p. 147; Montoya, 1985, p. 175, 199, 200 e seg.).

Convencidos pela contundência das palavras daquele cacique, os agressores regressaram às suas terras, de onde, brotaria, pouco tempo depois, uma nova redução - São Francisco Xavier. Nessa redução "se recolheram aquelas bestas feras e se domesticaram, mudando-se em ovelhas mansas". Fez tal "transformação a Palavra Divina e o batismo que todos receberam", que o gentio cresceu "a cada dia na fé, na virtude e afeição aos padres", como nos conta Padre Antônio Ruiz de Montoya. Esse acontecimento seria de grande importância para a Companhia nas suas entradas posteriores.

Durante os dois longos meses seguintes, Pe. Montoya partiu para mais uma nova tentativa de contato. Tão logo percebeu vestígios de uma nova tribo, pôs-se a uma boa distância do povoado. Enquanto isso ia se "informando a propósito dos costumes locais daquela província, procurando ao mesmo tempo dar daí àquela gente informes relativos à [sua] vinda e pretensões"? A sua chegada, no entanto, não foi tão hospitaleira como esperava. Percebendo um alvoroço dissimulado que pairava no ar, Montoya atravessou em vigília a noite, preparando-se para qualquer eventualidade. Logo cedo, nas suas orações, foi interrompido por um feiticeiro e 
convocado a explicar-se aos oito caciques que o aguardavam. Montoya imediatamente argumentou:

\begin{abstract}
"com palavras amorosas e brandas como o desejo e seu bem [o] tinham guiado às terras [deles], sendo que não era em busca de ouro e prata, que eles não tinham, mas em favor de suas almas. A estas, embora entenebrecidas pela gentilidade e pelos pecados, [ele] trazia algo que as houvesse de tornar brancas: era a água do batismo e neste a verdadeira crença em um só Deus, criador Universal" (Montoya, 1985 , p. 201).
\end{abstract}

A despeito da ferocidade do feiticeiro, que atalhando-o na sua predicação, acusou-o de mentiroso e incitou a comunidade a "experimentar a carne [do] sacerdote, a qual julgavam ser diferente e mais gostosa que a de outra gente", parece que há nesse fato, além da mera descrição da saga dos jesuítas em suas primeiras entradas, indícios reveladores de uma estratégia peculiar da Companhia.

Se atentarmos para a passagem da fundação da redução de São Francisco Xavier, em que os padres José Cataldino, Diogo de Salzar e Montoya se viram emaranhados no ardil de uma emboscada dos índios, encontramos lá o refúgio dos missionários nas palavras persuasivas e convincentes de um velho cacique que instigava muito apreço entre os seus. Tomados sob sua proteção, o cacique discorreu em sua falação na defesa dos jesuítas: a chegada dos padres não tinha por objetivo a peleja, o combate, pois, estavam desarmados. Nem também vieram roubar-lhes ouro ou prata, já que não os tinham. Almejavam fazê-los filhos de Deus e ensinálos o modo de bem viver, afirmava o cacique naquela ocasião.

Montoya, já celebrado naquela ocasião em suas exéquias pelas mulheres, depositou "ante as razões daquele bom cacique, a capitulação dos canalhas". Como podemos ver, a intervenção do cacique não só protegeu os padres como também facilitou a permanência do jesuíta na comunidade. Essas mesmas "boas razões" não foram, no entanto, suficientes ou eficazes, pouco tempo depois, na primeira tentativa de ocupação da província de Taioba. Como presenciamos, ele lança mão dos mesmos argumentos, quando recolhido ao aprisco dos caciques e do pajé, justificando sua presença: que não ambicionava riquezas que lá não havia e que o bem era seu guia. É evidente como reproduz os mesmos argumentos utilizados pelo cacique. Parece, então, que Montoya acreditou estar no argumento do cacique a decisão dos índios de 
não importuná-lo. Por essa razão, reproduziu esses argumentos em sua fala.

Contudo, fica a dúvida: por que o jesuíta, recorrendo à sua oratória contundente, tão própria da Companhia, utilizando-se dos mesmos argumentos, extraídos da própria fala do cacique, não obteve o mesmo resultado, ou seja, não teve sucesso com o gentio? Essa pergunta que, num relance parece de pouca importância, pode, entretanto, revelar indícios de uma problematização no confronto interétnico entre jesuítas e guarani. Entendemos que essa formulação pode direcionar o rumo de nossa investigação: como se deram os primeiros contatos, como foram conduzidos e qual foi a resposta dos nativos. Mas por enquanto, não nos adiantemos.

O contraste nessas duas passagens pode nos induzir a duas reflexões iniciais. A primeira aponta para o fato de que o livro de Montoya, A conquista espiritual, ter sido uma obra de propaganda da edificação da Companhia de Jesus. Os jesuítas, em diversas ocasiões, foram acusados por seus adversários de viverem em luxúria e ostentação. As afirmações de Montoya serviram assim para solapar a idéia de que os jesuítas buscavam ouro e prata, tão vivos no imaginário europeu. Colocada na boca do cacique a afirmação da inexistência de riquezas naquela região, não só assegurava a legitimidade de tal declaração como também minavam os alicerces das acusações proferidas contra a Companhia de Jesus. Por outro lado, esse relato de Montoya também poderia ter-se prestado em desencorajar aqueles que, ávidos em aventurar-se pela América, seduzidos pelo ouro, apenas adensariam o tumulto já causado pelos bandeirantes paulistas e colonos espanhóis. ${ }^{2}$

Mas a preciosidade desse documento está justamente na possibilidade de se acompanhar o processo da conquista, na leitura pendular que vai da Companhia de Jesus aos guarani, como pensavam e como reagiram, dentro de suas próprias categorias. A segunda ponderação é, por isso, o objeto de nosso interesse: os primeiros contatos. Antes, porém, permitam-me uma pequena digressão de caráter metodológico.

A historiografia tradicional considera, na passagem acima, que a fala daquele cacique enuncia, por princípio, uma versão a partir da visão jesuítica. Por ser registrada pelo punho dos jesuí-

\footnotetext{
Sobre essas acusações, veja, por exemplo, a defesa apresentada pelo Pe. José Cardiel, "Breve relación de las missiones del Paraguay" (Documentos, 1929, p. 586). Era muito divulgada nessa época a idéia de que havia um penhasco todo coberto de ouro. Resplandecente, a montanha reverberava o sol, e seu brilho ofuscava os olhos dirigidos a ele. Documentos, 1929 , p. 312.
} 
tas, aquela fala se perde como referência da posição indígena. Alguns, por isso mesmo, argumentam que, ao passar pelo crivo dos jesuítas, a fala indígena perde o seu ethos, o seu lugar representativo do que seriam as palavras dos indígenas naquele momento. Essa interpretação criou raízes e trouxe duas conseqüências. A primeira é a de que, ao não reconhecer a possibilidade de se fazer uma leitura desse acervo documental, extraindo da fala jesuítica uma leitura própria dos nativos do processo da conquista, relegaram ao anonimato o agenciamento histórico desse povo. Assim, circunscreveram a história ao âmbito da Companhia de Jesus. Eduardo Hoornaert, um dos mais renomados historiadores da Igreja, referindo-se às missões jesuíticas, faz afirmações surpreendentes nesse sentido:

"Decerto nunca conseguiremos realizar acerca dos aldeamentos o sonho de Leopoldo Ranke: 'escrever como foi realmente', não somente por falta de documentos mas sobretudo porque estes só representam o ponto de vista do missionário, não do indígena. A voz do indígena não foi registrada, nem o sofrimento dele nem muito menos seu ponto de vista" (Hoonaert, 1982, p. 7).

A outra conseqüência, e talvez a mais desastrosa, é interpretar a interferência do cacique, nessa passagem, como uma manifestação ou indício da submissão da comunidade indígena ao mundo ibero-cristão. Nessa perspectiva, a única leitura possível para alguns historiadores foi a do processo de aculturação, então, em curso. Portanto, a interpelação favorável do cacique não poderia ser considerada senão como manifestação do processo de dominação e intervenção da Companhia de Jesus.

Tais procedimentos metodológicos, nos parece, devem ser questionados. Levada ao extremo, tal atitude nos induz à idéia de que, se os documentos à disposição dos historiadores tivessem sido feitos pelo próprio cacique, a história estaria, naturalmente, resolvida. Poderíamos, nessa hipótese, recuperar "exatamente" o que os indígenas pensaram, como agiram no processo da conquista e colonização. Como não é esse o caso, nós, historiadores, estamos fadados, por isso, a construir a história a partir e exclusivamente da Companhia de Jesus. Afinal, é o que sugere tal visão. E isso não é o bastante se queremos resgatar a dinâmica daquele momento.

Adotar essa posição é negar as contribuições de ordem metodológica que, enfim, nos permitem abordar a documentação sob diversos enfoques, na medida em que outras questões são coloca- 
das, novas perguntas são postas. Esse é precisamente o desafio do historiador. Creio, por essa razão, que essa conduta recorrente em alguns historiadores merece críticas severas, porque é por si só falaciosa e improcedente.

Ainda assim, se não podemos assegurar que a fala do cacique foi ou não reproduzida pelo jesuíta de forma verossímil, é justamente através daquelas palavras que podemos entender como foram possíveis os primeiros contatos. Se a versão apresentada pelo jesuíta, naquele momento, não corresponde exatamente às palavras do cacique, argumentam alguns, certamente importa muito ver que o fato de o cacique falar em defesa dos jesuítas significou muito para aqueles que participaram daquele acontecimento. Por essa razão, há muito mais a se perceber do que simplesmente se enveredar nessa discussão: se as palavras são ou não fiéis à fala indígena. Impregnado de purismo, essa preocupação deixa escapar a significação dessa fala, a sua representação para aqueles homens.

Pouco significa a sucessão dos fatos, o que realmente aconteceu ou se a fala, reproduzida pela pena do jesuíta, atesta o que foi dito pelo cacique. "A frase exata não interessa tanto quanto as associações por ela evocadas", como nos lembra Robert Darnton (Darnton, 1990, p. 300). Se não podemos afirmar que o discurso do cacique se deu tal qual foi reproduzido pelo jesuíta (de que aquelas palavras foram realmente o que o cacique teria dito), podemos extrair daquela passagem muitas outras inferências que nos ajudam a compreender os primeiros contatos.

Se com toda sua retórica persuasiva, recorrendo ao mesmo enredo, aos argumentos alegados pelo cacique em prol dos missionários, o jesuíta não obteve o mesmo sucesso entre o gentio, isso indica que, pelo menos em princípio, não importou "o quê" se disse para convencê-los. Por essa razão não é relevante saber se as palavras ditas pelo cacique condiziam ou não historicamente com a fala do chefe indígena. Resguardando as devidas proporções, é a fala do cacique que aponta para a dimensão social, para o sentido que aqueles indígenas deram ao discurso do principal. Afinal, o cacique evitou a chacina do padres. E aqui, consideramos, pode estar uma das chaves para se entender o processo dos primeiros contatos nos séculos XVI e XVII.

Como tentamos analisar, existe, em um primeiro momento, um sentido para a Companhia em depositar aquela "fala" nas palavras do chefe indígena. Não se pode negar esse primeiro dado. Mas para além disso, há ainda a possibilidade de outra considera- 
ção que foge a esse limite: perceber o que aquela fala, enunciada pelo cacique, pôde evocar para aqueles guarani. Queremos afirmar com isso que há um "significado social" que se deve privilegiar: no nosso caso, atravessar o sentido das palavras daquele cacique - e tal é a expressão disso, que não nos parece aqui fundamental discutir, em princípio, o teor do discurso do cacique: "o quê" se disse. O que consideramos relevante é, acima de tudo, "quem" o disse. Em outras palavras, o que é revelador não é somente a fala, os argumentos usados, mas o fato de ser o cacique e não o jesuíta a enunciá-la. Isso pode fazer grande diferença. Nesse sentido, se nos fizemos claros, poderíamos interpretar o insucesso de Montoya entre os da província de Taioba por não ser o cacique o porta-voz, aquele que falou em nome dos jesuítas - o seu mensageiro. O que pode parecer um adendo ou detalhe toma vulto em nossas indagações, porque implicou em uma certa prática que deu contorno à intervenção dos jesuítas.

Mas, voltemos ao nosso relato e acompanhemos o rumo dos fatos - eles por si só mostrarão a força dessa conduta. Perseguidos pela torpe de índios, Montoya e sua comitiva foram atacados por flechas, deixando de flanco alguns dos companheiros. Nada adiantou a sua tentativa em reproduzir as palavras do cacique. Com o insucesso, ele percebeu que recorrer ao argumento do cacique não garantia sua penetração no seio da comunidade. $\mathrm{O}$ cacique ou principal, como era comumente chamado, tinha ascendência sobre a comunidade, concluía o padre. Por isso era fundamental ganhá-lo.

Para Montoya, "com sucesso tão adverso pretendia o demônio arredá-[los] de empresa tão importante, mas a avidez de ganhar tantas almas para o céu fazia olvidar esses trabalhos". Assim, decidiu-se novamente a fazer outro assalto àquele "alcácer", tão "apetrechado de ardis do demônio e fortificado com tantos ministros seus". Acompanhado com o ânimo destemido daqueles índios que não se acovardaram, o missionário pôs-se a preparar uma nova investida. Com certeza, depois da experiência melindrosa do seu primeiro ensaio de contato, o jesuíta já havia percebido que para além das palavras, o "ventríloquo" dos missionários haveria de ser escolhido a dedo. Nada adiantou ter tentado recorrer aos mesmos argumentos do cacique que lhe salvara a vida anteriormente.

Como ele afirmava, "em cristandade nova usa Deus de métodos novos [...] e ainda de águas de irrigação necessárias, para que plantas tenras, como as dos índios, cresçam em virtude e aumentem a graça". Para percutir a palavra de Deus eram de impor- 
tância crucial "novos métodos". Foi por ver ao longe a força dessa descoberta que Montoya "desejou ir ver o grande cacique Tayoba, por julgar que ganho ele, teria os demais de [seu] lado". Montoya, a partir da sua experiência, começava a usar o seu novo recurso: "ganhar" o cacique.

Fato é que, "por vontade do Senhor", e certamente instigado pela curiosidade de ver o missionário, veio a aldeia um grande cacique. "Sinal evidente de amizade", deduziu, com argúcia, o padre. Acolhendo-o com muita honra, Montoya, aproveitando-se do "fascínio que sobre ele exercia", travou uma longa conversa. O padre aproveitava a atenção do cacique para criticar o modo de proceder intratável dos pajés. O cacique, assegurado do grande logro que lhe foi pregado pelos pajés, e a pedido do jesuíta, não retardou em servir-se de embaixador junto ao seu velho companheiro - o cacique Taioba (Anais, 1878, p. 199, 221; 52, 84, 110, 111, 163). Grande proveito tirou-se desse encontro: logo tratou o missionário de entrar, novamente, nas terras de Taioba. E o resultado não foi outro senão a acolhida do renomado cacique Taioba.

Assim, conclui o próprio Montoya, "foram eles cobrando amor às palavras" ajudado nisso pelos "seus companheiros [os caciques] com as suas, falando bem aos gentios". Estes, "verdadeiramente informados a propósito de [suas] intenções, apresentavam-se cada dia em tropas, trazendo consigo suas mulheres, seus filhos, seus enfermos, seus bens e pequenas posses", para povoarem aquele posto e nele ouvirem a Palavra Divina (Montoya, 1985, p. $163,114,115,116,118,120,122)$. Esses relatos são, pois, bastante elucidativos porque demonstram, pela sua exegese, uma conduta ímpar naquele momento dos primeiros contatos. Como alude Montoya, "por armas essa gente foi inconquistável; conquistou-a pelo Evangelho [...] e com a caridade e paciência de Cristo".

Acompanhemos um pouco mais o que, a partir desse aprendizado, fizeram os jesuítas espanhóis em outras tentativas de contato que se seguiram à experiência com o cacique Taioba. $\mathrm{O}$ cacique Ayerobia, também convertido na redução de Santa Ana, batizado como Bartolomeu "encarregou-se de [...] aguilhoar os gentios remissos ao batismo". Na redução de São Carlos é Montoya quem relata entusiasmado: "E esse, que hoje em rebeldia corre pelos matos, já manso amanhã, ajuda a nossos padres a rastrear outros, sendo assim que se leva avante a conquista espiritual". Ou na redução de Caraó em que o famoso cacique, conhecido por Tambavê, tornou-se "criado dos padres", "num ofício de caridade para com os enfermos bem como outros trabalhos humildes". Trans- 
formado em Paulo, "grande foi sua eficácia em pregar a Cristo", "[...] contribuiu na conversão de muitos gentios, os quais (hoje) gozam do batismo e da fé cristã". Nos conselhos que dava, insistia para que todos servissem a Deus e "fugissem das persuasões fraudulentas dos feiticeiros" (Montoya, 1985, p. 224, 208, 204). Não seria outra a conduta na tentativa de catequese do gentio de Tebiquari que "estava aun mui poco dispuesto y nada afeta a nosostros y assi no trate mas que de ganarlos hable, y procure ganar los caciques de mas nombres" (Cortesão, 1951, v. 3, p. 98, 121).

De certa forma, esse primeiro contato também significou penetrar, mesmo que sem o seu entendimento amplo, na cosmovisão indígena. O Padre Montoya, mentor e ideólogo das maneiras de se granjear o gentio, foi um etnógrafo à moda de seu tempo. Apesar de cerceado pelo horizonte religioso que se lhe impunha, não perdeu de vista a possibilidade de recriar "novos métodos" para a conquista espiritual do gentio. Se como vimos, a primeira tentativa foi malograda, serviu-lhe como demonstração: primeiro, percebe que a ajuda de um intérprete era eficiente, depois que esse intérprete nem sempre auferia vantagens e, portanto, deveria ser bem escolhido. Assim, tentou transformar o simples intérprete ou "linguaraz" em um indígena convertido, mas o insucesso persistia. Apesar disso, avançou por conta própria, sem sucesso. Com as novas entradas, percebeu que precisava de um "ventríloquo" alguém que realmente intermediasse a relação jesuíta/indígena. Mas mais que isso, entendeu que ele não poderia ser qualquer um. Ao compreender a importância disso, logo se pôs a privilegiar o contato com o cacique - já notara que através dele, de sua interferência favorável junto à comunidade, utilizando-se dele como emissário da palavra divina, muito, mas muito mais se angariaria. E aqui, ele dimensionou seu ganho. Não é assim, aleatório o fato de que nas sucessivas entradas dos jesuítas muito se prezasse a conversão do cacique. Ao fazê-lo, os missionários encurtavam e aceleravam o rebento de seus frutos.

Espalhadas por toda a descrição da odisséia dos jesuítas, na fundação das missões, nos séculos XVI e XVII, estão pontuadas reflexões e considerações sobre como bem fazer a conquista espiritual - suas experiências, seus aprendizados, suas descobertas. Informações que, tecidas pela rede sub-reptícia de cartas e escritos que circulavam entre os irmãos da Companhia, serviam como manuais de catequese, um "breviário" de conversão do gentio.

Tentamos traçar o caminho que possibilitou a penetração da Companhia de Jesus, trilhando seus percursos, acompanhando 
junto com eles sua lógica. Ao se aproximarem do gentio, o que configurou uma certa estratégia de contato, os jesuítas acreditaram estar garantindo o sucesso de sua empresa. Com isso os padres acreditavam ter o domínio sobre toda a comunidade. No entanto, para o engano da Companhia, não parece ter sido bem essa a interpretação dos caciques. Se a conduta dos jesuítas pressupunha uma aproximação com o gentio para então convertê-los, parece não terem percebido que continuavam atados aos valores da comunidade guarani - o que certamente foi decisivo naquele processo.

\section{O avesso da Ordem: a leitura guarani}

Montoya, conforme ele mesmo declara, já havia compreendido o quanto se fazia importante cooptar o cacique. O primeiro alerta, a partir daquele episódio, foi a compreensão sobre as relações de poder na comunidade indígena. Mas, isso não bastou para os interesses dos jesuítas. Para muito mais eles haveriam de se atentar. O mais notável foi a descoberta da sustentação desse poder: é que a soberania e autoridade eram reconhecidas pelos guarani não só por ser o cacique seu chefe mas pela forma que proferia sua arenga, sua fala. O que mais impressionava a todos era a enunciação, o discurso eloqüente do seu chefe. O principal era bastante "estimado e admirado pela sua nobreza e eloqüência", reconhecia o jesuíta, que se serviria em muito dessa conclusão. Em uma das passagens mais brilhantes, o padre desvendaria os laços do poder entre os guarani:

"Eles [os pagãos] têm também os seus chefes, que os regem e ordenam o como devem proceder. São os homens principais. A eles se submete a demais gente que os acata obediente. Para a posição de chefe é de ordinário designado aquele que pertence a família de algum chefe falecido, há porém outros que com as suas bonitas falas somente ajuntam gente, com as suas arengas a persuadem e a seduzem e afinal reduzem-na, e tornam-na sujeita (vassala). Essa gente em verdade cumpre os seus ditames, e os venera como aqueles que sabem no que podem bem empregá-la. Para o principal preparam as roças, plantam-nas e fazem a colheita os seus camaradas, fazem também para ele a casa, e si o principal desejar as filhas de qualquer dos camaradas, o pai lhas dá sem procurar saber o que há. Por esta maneira encontramos chefes que se tinham amasiado com 15, tinham outros 20 e outros ainda 30 mulheres" (Anais, 1878, p. 107). 
Certo é que se a interferência do cacique foi de fundamental importância, muito mais foi a força de sua persuasão. Para os guarani, como apontou Montoya, "as falas bonitas" indicavam um grande valor. De fato, ele percebeu bem: o domínio sobre "palavra" era sinal de domínio e poder. A escolha do chefe, antes de tudo, se dava pela sua capacidade retórica. Nesse sentido, quem dominasse a língua, sua discursividade, detinha o poder sobre os outros. Apesar de longa, vale a pena reproduzir a citação de Montoya, por expressar de forma extraordinária o que percebeu tão bem entre os guarani:

"muitos se enobrecem com a eloqüência no falar, pois tanto estimam
a sua língua e é com razão que o fazem, porquanto é digna de lou-
vor e merece celebrar-se entre as de fama. É com ela que agregam-se
gente e vassalos, com o que ficam nobres eles e seus descendentes.
Servem-nos seus plebeus, fazendo-lhes roças, semeando e colhendo
as safras, construindo-lhes casas e dando-lhes as suas filhas quando
têm desejo delas" (Anais, 1878, p. 52).

Os padres se convenceram de que a intervenção favorável do cacique implicava na acolhida dos jesuítas, e por conseqüência, uma predisposição para a conversão. Todos se jubilavam com a iniciativa de vários caciques que assumiam o papel de pregadores na comunidade. No entanto, como observaremos nos relatos que se seguem, mesmo quando os padres eram aceitos na comunidade, era o cacique o responsável pela predicação. Em todas as passagens o cacique era o pregador, o orador por excelência e, em nenhum momento, conferiu o lugar do púlpito para o jesuíta. Em diversos relatos encontramos os caciques se incumbindo da doutrinação. Vejam, no exemplo, como os caciques atuavam, conforme relatavam os padres:

"levanta antes del dia [como lo hacia antes en servicio del demonio] i hace una platica por todo el pueblo exortando a todos que amen á nuestros Padres [...] i tiene mucha gracia y abundancia de palavras i eficacia en elas".

Sobre o cacique Neeazâ, depois de batizado e receber presentes, se comentava: "de rara elocuencia como lo muestra su apelido, que tenia desde antes del bautismo i significa platica engazada, para explicar conforme a su frase el concierto i eficacia de las suyas". Dele muito proveito se obteve. A atuação de Caraguari foi também bastante fértil, pois era "muy elocuente tanto que los mismos padres se admiraban de él, pues, hacía con la gente lo que 
queria". Em São Cristóvão, os índios se ajuntavam com o desejo de serem batizados. Foi Antônio, um velho cacique, quem conseguiu tamanha façanha. Depois de batizado, voltou às suas terras, e se tornou "instrutor da gente". Ao padre propunha: "Aos nossos filhos somente ensinem os padres e depois disso os nossos filhos por si mesmos poderão mui bem vir ensinar-nos". O Padre Roque Gonzales, o famoso mártir das missões, enviado ao Paraná, "despues de aver acariciado algunos caziques e indios del rio [...] entró en su tierra, oyeron la palabra de Dios en su propria lengua en q. hablava" (Anais, 1878, p. 357, 358; Documentos, 1929, p. 359-735; $327,328,359)$.

Nesse sentido, o cacique não poderia ser tão eficaz, como intermediário, se não contasse com a conivência de toda a comunidade. Por isso, não adianta muito pensar no cacique como mero ventríloquo, como pretenderam os padres, mas sim reconhecê-lo como o único agente capaz de convencer o gentio. Isso, naturalmente, foi muito importante, porque implicou no reconhecimento de que a legitimidade da fala estava ainda nas mãos do cacique. Assim, essa estratégia só se viabilizou a partir dos próprios limites que a cultura indígena impôs.

O que é importante ressaltar a essas alturas é que não somente os jesuítas definiram como realizar a aproximação mas a própria comunidade guarani imprimiu sua visão a essa escolha. Se os missionários perceberam que o confronto não era uma boa política e que o cacique era um instrumento imprescindível; por outro lado, a comunidade indígena elaborou oportunamente a chegada dos padres a partir dos seus próprios referenciais. $\mathrm{O}$ reconhecimento da importância do cacique e, sobretudo, do poder simbólico da eloqüência, assegurou a penetração dos jesuítas na comunidade. Mas isso só foi possível porque o indígena, como vimos, era ainda o sujeito de sua própria fala. $\mathrm{O}$ cacique, por isso, não foi o embaixador dos jesuítas, seu ventríloquo (como imaginavam os padres), mas perseverava como aquele que era o detentor da fala, do discurso para a comunidade. Afinal, como percebemos, é ele, exclusivamente, quem prega aos indígenas.

De certa forma, ao abrirem mão, nesse momento, da predicação (porque acreditavam que o cacique realizava, com eficácia e proveito, esse papel), os padres estavam concedendo muito mais. Ao permitirem que o cacique exercesse o ato da pregação, sob a alegação de que maiores frutos colheriam, os padres se viram enredados num outro ardil: de fato, estavam sujeitos aos parâmetros culturais dos nativos. Não se pode deixar de reconhecer, portanto, 
a profundidade de tais relações e o quanto os jesuítas estavam imersos aos valores dos guarani.

Muito embora a língua aparentemente se constitua como uma estrutura linear, ela não tem a mesma significação e valor comuns a todos os povos. Na realidade, transgride essa acepção que lhe impõem e cria diferenças sensíveis, personalizando cada comunidade lingüística. Cada comunidade sobrepõe à sua língua uma maneira distinta, uma significação própria, caracterizando-a com a força de sua cultura. É justamente o que fizeram os guarani. Assim, a comunidade guarani imprimiu à língua um sentido maior que o da comunicação: elevou a linguagem ao nível do reconhecimento próprio na comunidade.

A retórica, o poder persuasivo da linguagem tem por isso toda uma especial conotação para os nativos. Esse discurso não era meramente pessoal, particular, próprio do cacique que se dizia "dono" de sua fala. O discurso do cacique esteve sujeito à ordem sócio-cultural guarani. Essa bagagem cultural indígena só pôde emergir pela mediação do diálogo, onde a linguagem criou vida na busca do reconhecimento do Outro. Assim, o valor daquela discursividade existiu enquanto se toma o plural, quando se considera o conjunto da comunidade guarani. A fala do cacique era fundamental, porque é nela que a comunidade se expressava, se reconhecia. Nesse sentido, essa maneira própria e peculiar de relação com a língua foi um dos grandes traços distintivos que caracterizou o guarani colonial. A língua, mais que o sentido da comunicação, pode ser, assim, considerada como um dos elementos da "bagagem ou acervo cultural" da comunidade indígena. Foi, por isso, marco do ethos do povo ou da cultura guarani.

Nesse sentido, fez muita diferença para os guarani ser o cacique o enunciador da pregação. Por isso, temos que reconhecer que esse foi um traço valorativo da comunidade. Para levar adiante a fundação das missões, a Companhia foi obrigada a se sujeitar aos valores culturais dos guarani, ou seja, admitir que o sucesso de seu empreendimento estava nas mãos do cacique. No entanto, para o indígena ele ainda era dono de sua própria fala, sem, em momento nenhum, delegar aos padres tal privilégio. Daí não fazer efeito algum os padres se utilizarem dos argumentos do cacique, pois o que é relevante para a comunidade guarani é o fato de ser o próprio cacique aquele que enunciava a prédica. Sem esse dado, certamente, o empreendimento da Companhia seria estéril e infrutífero. Nesse sentido, a tentativa de conversão do gentio pressupôs estratégias que implicaram em visões tanto para os padres como 
para a própria comunidade guarani. Foi uma experiência datada que envolveu interpretações diferentes do processo de conquista e que, portanto, deve ser revista sob a ótica dos atores daquele tempo. É é nessa teia de valores que os padres emaranharam-se.

Se, por um lado, o aprendizado da língua guarani buscou interferir, decididamente, e reformular a mentalidade indígena, facilitando a penetração de conceitos estrangeiros a essa realidade, como argumentam alguns; por outro lado, o empenho e dedicação da Companhia de Jesus em aprender com eficácia e prontidão a língua nativa, nos leva a outras considerações. Na Segunda Instrução de 1610, o Pe. Torres, esclarecendo sobre as ocupações em que se deviam dedicar os irmãos, assinalava para o empenho no aprendizado da língua e que esta "se atendesse com muito cuidado sempre, não se contentando em sabê-la como se queira, mas com eminência".

Para atender tal exigência da Companhia, os jesuítas vão se dedicar com bastante afinco ao aprendizado da língua guarani. Entre longas horas dedicadas aos estudos e exercícios espirituais, se propuseram a aplicação dos estudos: treinando a conversação ou vertendo orações e textos para o guarani. ${ }^{3}$ Não parece ser fortuito o fato de os padres se prontificarem a cada dia a se aprimorarem e exercitarem, com fluência, a língua, como relata Oñate: "hemos puesto este año muito cuidado na lengua", procurando falar novos vocabulários por meio de uns índios e assim "la bamos muy bien desentrañando" (Documentos, 1929, p. 36). Se a intervenção do cacique foi vital, o domínio sobre a língua era um imperativo. Por isso as recomendações são inúmeras:

"el examen particular sera de no perder punto en aprender y estudiar la lengua guaraní, y ejercitarla con los indios fuera del tiempo de oración y ejercicios espirituais, en todos los cuales, y principalmente en la misa, los encomendarán á Dios Nuestro Señor, la Compañía, esta provincia y necesidades de la Santa Iglesia" (Documentos, 1929, p. 581).

O domínio da língua, então, é encarado como uma dádiva divina, o consagrado dom das línguas. O provincial Pedro de Oñate, referindo-se às virtudes do padre Montoya, conta que ele se

Essa preocupação será uma recorrência em toda a documentação. Cf. Wiliam Bangert, 1985, p. 47. Em 1603, o Pe. Provincial Claudio Aquaviva, em uma Instrução para "afervorar a doutrinação dos índios", determinava que nenhum dos padres se ordene como sacerdote sem primeiro saber bem a língua e que nem a ele seja facultado ministrar a confissão ou mesmo sua promoção antes que domine com perfeição o guarani. 
dedicava com afinco a "uma arte e vocabulario en la língua guarani e segundo me escrevem os padres arece que N. Sr. lhe há comunicado o dom das línguas segundo é a facilidade, brevedad e excelencia com que fala" (34). O Padre Chavanag, algum tempo depois, reconhecia que a dificuldade da língua e seus caracteres exigia um singular gosto pelos estudos. Mas dedicava-se com esmero ao estudo "sin buscar en èl otro agrado, ni aliciante, que su utilidad, para servir algun dia à la gloria de Dios con fruto" (Documentos, 1929, p. 97). Agora é possível entender por que os Superiores da Companhia chegaram ao ponto de exigir que não se ordenasse nenhum missionário, antes que dominasse fluentemente a língua nativa:

"a ninguno de los N. N. se ordene de sacerdote sin que primero sepa bien la lengua: y para facilitar esto, que en tiempo de la tercera probación tengan tiempo señalado para elo: y que si acaso por no perder la ocasión, fuera necesario se ordenen antes de saberla, que no se ocupen en ministerios hasta saberla bien" (Cartas edificantes, 1753, I, p. 239).

A língua favorecia, naturalmente, a tradução do conteúdo cristão para os índios. Mas mais que isso, e acima de tudo, também revelava em si mesma uma importância cultural para o guarani. A fala, aqui entendida como a capacidade retórica, foi um dos elementos mais valorizados entre os guarani, como vimos. Esse fato colocou o jesuíta em uma atitude de respeito frente à língua, porque ela trazia um sentido divino e sagrado para os indígenas. A fala era, enfim, o fundamento da cultura guarani. Melià reconhece essa força e expressão para os guarani:

"Dentro de una reducción que intentaba legar hasta el núcleo de cultura guaraní, la lengua no podía dejar de ser tocada. La palabra es el alma: el Guaraní encuentra su fundamento en la palabra. También aquí quitarle la palabra sería arrancarle el alma" (Melià, 1981, p. 251).

Embora as discussões lingüísticas tenham avançado sobre o sentido da língua guarani, composta e construída pelos jesuítas, nem sempre seu uso atendeu exclusivamente ao objetivo de distorcer ou incluir conceitos no imaginário guarani. 


\section{Conclusão}

Para garantir a eficácia da conversão, certos da importância da língua, os padres, exaustivamente, se aperfeiçoavam no aprendizado da língua guarani, procurando tornarem-se os mestres do "ñeengatú", das "belas palavras". No entanto, é precisamente pelo fato de o padre apostolar na língua nativa que ele continuava sujeito ao parâmetro de valor da própria comunidade que imprimia à língua um caráter sagrado. Ao se despojar do latim ou espanhol, em nome da língua nativa, os padres fizeram senão reafirmar os valores dos guarani. O indígena, portanto, também fez sua leitura.

Em outras palavras, se a tradução de conceitos e idéias para o guarani interferiu na realidade conceitual do indígena, o mais importante, nos parece, é o fato de que, de uma forma sutil, os indígenas obrigaram os jesuítas a se submeterem aos seus valores. O papel do cacique, o valor da língua e, depois, a capacidade retórica foram um primeiro marco dessa relação. Nessa perspectiva, poderíamos afirmar que a penetração da Ordem de Jesus só foi possível porque os padres estiveram todo o tempo submetidos à apreciação e valores indígenas.

Ao mundo guarani os jesuítas tentaram impor a produção de novos hábitos, mas não introduziram novas formas de pensar a realidade, porque a considerar o que vimos, o indígena preservara os seus valores. Se foi possível aos jesuítas a sutileza e percepção da importância incontestável da "discursividade" para os guarani, para a comunidade ainda importava o fato de ser o cacique o enunciador do discurso ou de o padre proferir sua doutrinação em "ñeengatú".

Assim, a palavra, o discurso não foi mais tomado pelo seu caráter intacto, original, mas sugestionado por novas relações. Essa relação interétnica foi ímpar no processo de conquista. A Companhia de Jesus não destruiu, mesmo que assim pretendesse. Desejou modelar e substituir, esvaziar e preencher. Com certeza, visava excluir, mas se viu obrigada a combinar, porque esteve sujeita aos parâmetros culturais dos nativos. Porque, como tentamos elucidar, a língua guarani não foi somente um veículo ou canal de comunicação, mas parte indissociável da própria tradição cultural do povo guarani. Dessa forma, o guarani reafirmava seus valores. Nesse sentido, parece que as interpretações diferiram: aquilo que o jesuíta acreditou como a apropriação do discurso indígena, era para o guarani a afirmação de seu próprio mundo. 


\section{Referências bibliográficas}

\section{Documentos impressos}

ANAIS DA BIBLIOTECA NACIONAL DO RIO DE JANEIRO publicados pela Biblioteca Nacional, Imprensa Nacional, v. 6, 1978.

CARTAS JESUÍTICAS - Cartas do Brasil. v. I, II, III, Belo Horizonte, Itatiaia, 1988.

CARTAS EDIFICANTES y CURIOSAS ESCRITAS DE LAS MISIONES ESTRANJERAS por algunos misioneros de la Compañia de Jesus, 1699-1754. Trad. Pe. Diego Davin, Madrid, Oficina de la viuda de Manuel Fernandez, Imprensa del Supremo Consejo de la Inquisicion y la Reverenda Camara Apostolica, 1753/1757, v. II/III.

CONQUISTA ESPIRITUAL feita pelos religiosos da Companhia de Jesus nas Províncias de Paraguai, Paraná, Uruguai e Tape. Trad. Arnaldo Bruxel. Porto Alegre, Martins Livreiro, 1985.

DOCUMENTOS PARA LA HISTORIA ARGENTINA (Cartas Anuas de la Provincia del Paraguay, Chile e Tucumán, e la Compañia de Jesús - 1615/1637), Tomos XIX, XX, Buenos Aires, 1929.

HERNÁNDEZ, Pablo S.J. - "Apéndice Documental". In: Organización social de las doctrinas guaranies de la Compañia de Jesus. Barcelona, Gustavo Gili, 1913, vol. I, p. 509-601; vol.II p. 511-723.

HISTORIA DE LA COMPAÑIA DE JESÚS EN LA PROVINCIA DEL PARAGUAY (Argentina, Paraguay, Uruguay, Perú, Bolivia y Brasil) según dos documentos originales del Archivo General de Indias, extractados y anotados por Pablo Pastels. Tomo I, II, Madrid, Librería General de victoriano Suárez, 1912/1915.

\section{Bibliográficas}

AYROSA, Plínio M. da Silva. Apontamentos para a bibliografia da língua guarani. 2. ed., São Paulo: USP, Boletim 169, n. 28, 1954.

BANGERT, Wiliam S. I. História da Companhia de Jesus. Porto: Livraria Apostolado da Imprensa, 1985.

BERTONI, Moisés Santiago. La lengua guarani como documento historico. In: Annaes do XX Congresso Internacional de Americanistas. Rio de Janeiro: Imprenta Nacional, 1932.

CAMARA, Mattoso. Introduçāo às linguas indígenas brasileiras. Rio de Janeiro: Livro Técnico, MEC, s.d.

DARTON, Robert. O beijo de Lamourette. São Paulo: Companhia das Letras, 1990.

HOONAERT, Eduardo (org.). Das reduçōes latino-americanas às lutas indigenas atuais. IX Simpósio Latino-Americano de Cehila. São Paulo: Paulinas, 1982.

MELIÀ, Bartolomeu. El modo de ser Guaraní en la primera documentación jesuítica (1594-1639). Revista de Antropologia, v. 24, São Paulo: 1981.

- El guarani conquistado y reducido. Asunción: Centro de Estudios Antropologicos, Universidad Catolica, 1988.

ORLANDI, Eni Pulcineli. Política lingüística na América Latina. Campinas: Pontes, 1988.

- Terra à vista - Discurso do confronto: Velho e Novo Mundo. São Paulo: Cortez, 1990.

SCHADEN, Egon. Aspectos fundamentais da cultura guarani. São Paulo: Ed. Pedagógica Universitária, 1974. 